\title{
SELF-IMAGE CONGRUITY AND ITS IMPACT ON WINE TOURISM
}

\author{
Marlene A. Pratt, Griffith University, Australia
}

\section{INTRODUCTION}

Consumer decisions involve not only rational and utilitarian attributes, but also value and symbolic attributes of a product or service. Self-image congruity models are based on the notion of the cognitive matching between value expressive attributes of a given product or brand and the consumers' self-image (Sirgy and Johar 1985). This research investigates the impact of self-image congruity on wine tourism behaviour, specifically winery/cellar door visitation, with the inclusion of functional and affective destination image constructs of wine regions, and attitude toward wine tourism. There is a lack of evidence within the tourism literature of the effect of self-congruity on the intentions or motivations to visit a destination (Chon 1992; Litvin and Goh 2002; Sirgy and Su 2000). In addition the researcher is interested in the potential differences of consumers who are considered high involved wine consumers vs those who are low involved wine consumers, and the impact on the self-image congruity model. Involvement as a construct is well established in wine purchasing behaviour (Lockshin, Jarvis, d'Hauteville and Perrouty 2006; Lockshin, Quester and Spawton 2001; Lockshin, Spawton and Macintosh 1997; Lockshin and Spawton 2001; Quester and Smart 1996; Rasmussen and Lockshin 1999; Zaichkowsky 1985). The link between wine involvement and wine tourism activity however, has only recently been explored by Brown, Havitz and Getz (2006), who developed a wine involvement scale (WIS). Similarly limited research has been conducted evaluating the effect of involvement with self-congruity. One study found the effect of involvement moderated the effect of congruity where the greater the involvement with travelling, the more important self-congruity is (Beerli et al., 2007).

\section{METHODOLOGY}

A sample of 5000 wine consumers was purchased from a mailing house. Three thousand wine consumers were sent a survey via email broadcast, and 2,000 were sent a survey via direct mail. The final sample size of 696 provides a margin of error of approximately $\pm 3.7 \%$, and a response rate of $13.9 \%$. An incentive package was developed that involved a prize draw of a bottle of Penfolds Grange 1991, second prize a bottle of Wolf Blass Platinum 2004 and three runners up received a Tenterfield saddler picnic blanket.

The dependent variable within this research study is consumers' intention to visit a wine region. Three items were used to measure intent, adapted from Dabholkar and Bagozzi (2002), Sparks (2007b) and Getz and Brown (2006), on the basis of work of Ajzen and Driver (1992). Self-congruity was measured using the direct score approach focusing on the image of users/or in this research study visitors to wine regions. Using the direct score approach requires a numeric scale to measure the level of congruence and this is facilitated by a scenario type directive and statements (Ekinci \& Riley, 2003). The final construct comprised four items encompassing actual self-image, ideal self-image and social self-image. These items were based on measures used by Sirgy et al. (2000) Goh and Litvin (2000). Functional destination image attributes was gathered from destination image researchers (Leisen, 2001), and in particular wine destination research (Getz \& Brown, 2006; Williams, 2001b). Affective destination image comprised items from Russell's (1980) scale which was felt to be relevant to wine tourism, as well as other affective items used by Jang and Cai (2002), Baloglu (1999), and Beerli and Martin (2004). Attitudes toward wine tourism measure is a standard unidimensional measure of attitude used by Ajzen (1987). The involvement scale used was based on a Wine involvement scale developed by Brown, Havitz and Getz (2006) together with items by Lockshin et al (2001).

Structural equation modelling was used to test the model, using Lisrel 8.72 to test the measurement and structural part of the model. Finally the effect of wine involvement as a moderating influence on respondents' intentions to visit a wine region was tested using multigroup analysis.

\section{RESULTS AND DISCUSSION}

The sample consisted of respondents from across Australia, fairly evenly split between genders. The average age of the respondents is 46 years old, with the life stage of the respondents varying. Household income also varied, with $45.3 \%$ earning between $\$ 100,001-180,000$. The vast majority of respondents have previously visited a wine region (94\%), with an average visitation is 8.7 within Australia. The majority of respondents are considered regular wine consumers, where $43.2 \%$ of respondents consume wine most days or every day, and $37.3 \%$ of respondents consume wine weekly. 
The measurement stage of the analysis was conducted using SPSS 16.0 and Lisrel for the confirmatory factor analysis. The final step in the analysis process is investigating the relationships among the latent variables through the structural model. The structural model contains 3 exogenous latent variables; self-image congruity, functional destination image, and destination affect, with 2 endogenous latent variables: attitude toward wine tourism, and intentions to visit wine regions. The proposed model was fitted to the data through MLE using Lisrel 8.72. The overall fit of the structural model to the data resulted in acceptable statistics as follows: $\chi^{2}=271.29(d f=126, p<.000)$, CMIN $=2.2$, CFI $=0.99$, RMSEA $=0.04(.034$, .047) and SRMR $=0.03$. The minimum fit function $\chi^{2}=264.24$. The chi-square is significant, however this is generally expected due to sample size (Anderson and Gerbing 1988; Hair, Anderson, Tatham and Black 1995).

Self-image congruity had a significant positive on intentions to visit a wine region, through the mediating variable attitude to wine tourism $(\gamma=0.14)$. Self-image congruity however, was found not to have a direct significant effect on intentions to visit $(\gamma=0.04)$. Functional destination image and affective destination image, both were also mediated through attitude toward wine tourism ( $\gamma=0.25$ and $\gamma=0.32$ respectively). Affective destination image provides a stronger significant relationship with attitude toward wine tourism, than self-image congruity or functional destination image. Neither functional destination image nor affective destination image had a significant direct effect on intentions to visit a wine region. As expected there is a strong positive relationship between respondents attitudes toward wine tourism $(\gamma=0.59)$ and their intentions to visit a wine region. Attitude toward wine tourism was found to be the mediating variable for each of the exogenous variables, on respondents intentions to visit a wine region.

When researchers are interested in employing involvement as a mediator of relationships among other consumer behaviour variables, then it is necessary only to use a measure of overall involvement (Mittal 1995), which was tested using multigroup analysis. The first stage in multigroup analysis is the determination of groups. Two factors were found for involvement, 'Interest' and 'Enjoyment' explaining 60\% of variance. 'Interest' was chosen as a high/low involvement differentiator as it explained the greatest amount of variance (48.52\%) of the involvement construct. A median split approach was used, similar to that used by Flynn and Goldsmith (1993). Multigroup analysis was conducted to establish measurement invariance across groups before conducting substantive cross-group comparisons. All the fit indices provide support that the same model form holds for both groups. With the high wine involvement group, both self-image congruity and affective destination image had a significant positive relationship to attitude toward wine tourism. The path between affective destination image had a stronger relationship with attitude toward wine tourism $\left(\gamma_{13}{ }^{(1)}=0.47\right)$ than self-image congruity $\left(\gamma_{11}{ }^{(1)}=0.15\right)$. High wine involvement respondents have a non significant path between the functional destination image and their attitude toward wine tourism. This differed with low wine involvement respondents, where their self-image congruity was not significant to their attitude toward wine tourism $\left(\gamma_{11}{ }^{(2)}=0.12\right)$, whilst functional destination image $\left(\gamma_{13}{ }^{(2)}=0.28\right)$ and affective destination image $\left(\gamma_{13}{ }^{(2)}=0.29\right)$, both were approximately equal in their effect on attitudes toward wine tourism. The relationship between attitude to wine tourism and its impact on intentions to visit a winery were positively significant for both high $\left(\beta_{12}{ }^{(1)}=0.47\right)$ and low $\left(\beta_{12}{ }^{(2)}=0.53\right)$ involvement groups.

The analysis of the model found that self-image congruity did not have a significant direct effect on purchase intentions as initially expected. This result however is not unique as it was also found in other research where self-image congruity did not directly impact intent (Cowart, Fox and Wilson 2008), but was significant with other consumer behaviours such as attitude, satisfaction and loyalty (Back 2005; Chon and Olsen 1991; Ekinci and Riley 2003; Ibrahim and Najjar 2008; Jamal and Goode 2001; Kressmann et al. 2006; Sirgy et al. 1997). Attitude toward wine tourism was found to be the mediating variable for each of the exogenous variables, on respondents' intentions to visit a wine region, demonstrating the strength of attitudes in consumer behaviour.

The involvement construct has been invaluable in providing greater understanding of the relationships within the model. The level of involvement with the product, that is wine, was found to have a strong moderating influence on behavioural intentions. Overall, respondents who were high wine involved consumers had high levels of self-congruity with a typical wine tourist, whilst low wine involved consumers did not. Both functional destination image and affective destination image had varying effects on attitudes toward wine tourism based on the level of wine involvement of the respondents. With the high wine involvement group, the affective destination image had a positive relationship to attitude toward wine tourism. The results suggest that the enjoyment and emotions attached to visiting a wine region overrides the other functional aspects. The functional construct was found not to be a predictor of wine tourism attitudes, which may be a result of the familiarity because of the number of times a high involvement wine consumer has previously visited wine regions. This would also lead to a greater understanding of the functional elements across wine regions and do not feel that the functional attributes is important. Although the functional construct was not significant in the model for high wine involved consumers, 
interestingly, one of the main factors of the functional image construct is the wine experience. Conversely, the main reason for visiting a wine region for high wine involved respondents was for wine specific reasons. The relationships within the model were different for low wine involved respondents. Both the functional destination image attributes and affective destination image attributes were approximately equal in their effect on attitudes toward wine tourism.

\section{CONCLUSIONS AND IMPLICATIONS FOR THEORY AND PRACTICE}

There are several theoretical implications which have arisen from this research study, including: the use of structural equation modelling (SEM) within self-congruity and tourism research; further development of the self-congruity construct, further development of the wine involvement construct; and image attributes attached to wine tourism and typical wine tourists.

This research is the only research within tourism literature to date which has measured self-congruity concurrently with both the functional destination image and affective destination image constructs in determining intentions to visit a destination. The measurement of the self-image congruity construct within this current study is also unique, in that a unidimensional construct was obtained through EFA and CFA analysis. This current study used the direct measure providing strong support for the predictive affect of self image congruity on consumer behaviour, together with the further development of the involvement construct.

Practical implications of the research include providing wineries and wine producers an understanding of the impact of selfimage in decision making. Furthermore, providing a working knowledge of market segments where self-congruity vs. functional and affective destination image attributes impact wine tourist's behaviour. The level of involvement also impact behavioural choices, which need to be recognised. The affective attributes or feelings attached to a wine region were the most powerful predictor of attitudes toward wine tourism and behavioural intentions for high wine involved consumers. These include affective elements such as: relaxed, a sense of escapism, pleasant, fun and a sense of discovery. Holiday tourism has a hedonic activity is particularly prone to emotional influence. Conversely, the functional destination image attributes of the destination were not found to be predictive in their decision to visit a wine region in the future. Another issue to consider is that the majority of wine tourists/visitors live locally, so they may not consider themselves to be tourists as such, and would view visiting a wine region as a leisure activity. As a result the functional destination image attributes (for example, quality wine, good restaurants' or the reputation of the region) did not impact their intentions as strongly as affect or feelings toward visiting a wine region. This supports the notion that wine tourists are interested in the experience and how they feel whilst visiting a wine region. Through the understanding of visitor image and destination image attached to wine tourism, wineries would be able to maintain or change their image to appeal to particular target markets, which is vital to ensure future growth of the wine tourism industry.

\section{REFERENCES}

Anderson, James C., and David W. Gerbing. 1988. "Structural equation modeling in practice: A review and recommended two-step approach." Psychological Bulletin 103 (3): 411-423.

Back, Ki-Joon. 2005. "The effects of image congruence on customers' brand loyalty in the upper middle-class hotel industry." Journal of Hospitality \& Tourism Research 29 (4): 448-467.

Brown, Graham P., Mark E. Havitz, and Donald Getz. 2006. "Relationship between wine involvement and wine-related travel." Journal of Travel \& Tourism Marketing 21 (1): 31-46.

Chon, Kye-Sung. 1992. "Self-image/destination image congruity." Annals of Tourism Research 19: 360-363.

Chon, Kye-Sung, and Michael D. Olsen. 1991. "Functional and symbolic congruity approaches to consumer satisfaction/dissatisfaction in tourism." The Journal of the International Academy of Hospitality Research 3: 1-25.

Cowart, Kelly O., Gavin L. Fox, and Andrew E. Wilson. 2008. "A structural look at consumer innovativeness and selfcongruence in new product purchases." Psychology \& Marketing 25 (12): 1111-1130.

Ekinci, Yuksel, and M. Riley. 2003. "An investigation of self-concept: actual and ideal self-congruence compared in the context of service evaluation." Journal of Retailing and Consumer Services 10 (4): 201-214. 
Flynn, Leisa R., and Ronald E. Goldsmith. 1993. "Application of the personal involvement inventory in marketing." Psychology \& Marketing 10 (4): 357-366.

Hair, Joseph F., Rolph E. Anderson, Ronald L. Tatham, and William C. Black. 1995. Multivariate data analysis with readings. Upper Saddle River, New Jersey: Prentice-Hall International, Inc.

Ibrahim, Hafedh, and Faouzi Najjar. 2008. "Assessing the effects of self-congruity, attitudes and customer satisfaction on customer behavioural intentions in retail environment." Marketing Intelligence \& Planning 26 (2): 207-227.

Jamal, Ahmad., and Mark. M. H. Goode. 2001. "Consumers and brands: a study of the impact of self-image congruence on brand preference and satisfaction." Marketing Intelligence \& Planning 19 (7): 482-492.

Kressmann, Frank, M. Joseph Sirgy, Andreas Herrmann, Frank Huber, Stephanie Huber, and Dong-Jin Lee. 2006. "Direct and indirect effects of self-image congruence on brand loyalty." Journal of Business Research 59: 955-964.

Litvin, Stephen W., and Hwai Kar Goh. 2002. "Self-image congruity: a valid tourism theory?" Tourism Management 23: 8183.

Lockshin, Lawrence S., Wade Jarvis, Francois d'Hauteville, and Jean-Philippe Perrouty. 2006. "Using simulations from discrete choice experiments to measure consumer sensitivity to brand, region, price, and awards in wine choice." Food Quality and Preference 17: 166-178.

Lockshin, Lawrence S., Pascale Quester, and Tony Spawton. 2001. "Segmentation by involvement or nationality for global retailing: a cross-national comparative study of wine shopping behaviours." Journal of Wine Research 12 (3): 223-236.

Lockshin, Lawrence S., Anthony L. Spawton, and Gerrard Macintosh. 1997. "Using product, brand and purchasing involvement for retail segmentation." Journal of Retailing and Consumer Services 4 (3): 171-183.

Lockshin, Lawrence S., and Tony Spawton. 2001. "Using involvement and brand equity to develop a wine tourism strategy." International Journal of Wine Marketing 13 (1): 72-81.

Mittal, Banwari. 1995. "A comparative analysis of four scales of consumer involvement." Psychology \& Marketing 12 (7): 663-682.

Quester, Pascale G., and J. Smart. 1996. "Product involvement in consumer wine purchases: Its demographic determinants and influence on choice attributes." International Journal of Wine Marketing 8 (3/4): 37-56.

Rasmussen, Michelle, and Lawrence S. Lockshin. 1999. "Wine choice behaviour: The effect of regional branding." International Journal of Wine Marketing 11 (1): 36-46.

Sirgy, M. Joseph, D Grewal, T. F. Mangleburg, J. Park, K. Chon, C. B. Claiborne, J. S. Johar, and H. Berkman. 1997. "Assessing the predictive validity of two methods of measuring self-image congruence." Journal of the Academy of Marketing Science 25 (3): 229-241.

Sirgy, M. Joseph, and J. S. Johar. 1985. "Self-image congruence models versus multiattribute attitude models: When to use what model for product positioning." In AMA Educators proceedings. Chicago, IL: American Marketing Association.

Sirgy, M. Joseph, and Chenting Su. 2000. "Destination image, self-congruity, and travel behavior: Toward an integrative model." Journal of Travel Research 38 (May): 340-352.

Zaichkowsky, Judith Lynne. 1985. "Measuring the involvement construct." Journal of Consumer Research 12 (3): 341-352. 